\title{
DETERMINASI KADAR TOTAL POLIFENOL TERLARUT, HESPERETIN DAN QUERCETIN PADA DAUN, KULIT DAN ISI BUAH Citrus aurantifolia (Christm \& Panzer) Swingle
}

\author{
Siti Mahyuni \\ Program Studi Farmasi FMIPA Universitas Pakuan Bogor \\ Email: sitimahyuni@unpak.ac.id
}

\begin{abstract}
ABSTRAK
Hesperitin dan quercetin adalah senyawa bioaktif golongan polifenol yang biasa terdapat tanaman genus Citrus sp. Hesperetin dan quercetin memiliki berbagai aktifitas farmakologis seperti antioksidan, antiinflamasi, antihipertensi dan mampu menurunkan kadar kolesterol dalam darah. Senyawa-senyawa tersebut tersebar pada berbagai bagian tanaman Citrus dengan kadar yang berbeda-beda, sehingga untuk proses ekstraksi yang optimal, perlu diketahui pola sebaran dan kadarnya pada bagian-bagian yang berbeda dari tanaman Citrus. Penelitian ini dilakukan untuk mengetahui kadar total polifenol terlarut, hesperetin, dan quercetin pada daun, kulit buah, dan isi buah isi buah Citrus aurantifolia. Hasil pengukuran kadar total polifenol terlarut dengan standar i menunjukan bahwa kadar total polifenol terlarut paling tinggi terdapat pada kulit buah $(6,954 \mathrm{mg} / \mathrm{g}$ berat basah) kemudian daun $(4,675 \mathrm{mg} / \mathrm{g}$ berat basah) dan isi buah $(2,243 \mathrm{mg} / \mathrm{g}$ berat basah). Kadar hespertin dan quercetin yang diukur menggunakan sistem high performance liquid chomatograpy (HPLC) menunjukan pola sebaran yang berbeda. Kadar hesperetin tertinggi terdapat pada isi buah 58,43 ( $\mu \mathrm{g} / \mathrm{g}$ berat kering) kemudian kulit buah $(32,49$ $\mu \mathrm{g} / \mathrm{g}$ berat kering) namun tidak terdeteksi keberadaannya pada daun. Sebaran senyawa quercetin menunjukan pola sebaliknya dimana kadar quercetin tertinggi terdapat pada kulit buah $(112,47 \mu \mathrm{g} / \mathrm{g}$ berat kering) dan terendah terdapat pada isi buah $(89,4947 \mu \mathrm{g} / \mathrm{g}$ berat kering) sementara pada daun buah terdapat quercetin dengan kadar $(92,71 \mu \mathrm{g} / \mathrm{g}$ berat kering). Dari hasil penelitian ini dapat disimpulkan hesperetin dan quercetin terakumulasi pada bagian yang berbeda dari tanaman Citrus aurantifolia.
\end{abstract}

Kata kunci: Citrus aurantifolia, hesperetin, quercetin, total polifenol terlarut

\section{DETERMINATION OF TOTAL SOLUBLE POLYPHENOL, HESPERETIN AND QUERCETIN CONTENT IN LEAVES, PEEL AND SAC OF Citrus aurantifolia (Christm \& Panzer) Swingle}

\footnotetext{
ABTRACT

Hesperetin and quercetin are the bioactive compounds commonly found on various part of Citrus sp plant. These compounds show many pharmacological activities i.e antioxidant, antihypertension, anti-inflammatory and reduce the level of cholesterol in blood circulation. Hesperetin and quercetin distributed and accumulated at different concentration in certain part of plant thus the distribution pattern of these compounds should be determined in order to optimize the extraction of the desired compound. This study was aimed to determine the content of total soluble polyphenol, hesperetin and quercetin in leaf, peel, and sac of Citrus aurantifolia using HPLC machine system. The results reveal that the highest total soluble polyphenol content was found in the peel of fruit $(6.954 \mathrm{mg} / \mathrm{g}$ fresh weight) followed by the leaves $(4.675 \mathrm{mg} / \mathrm{g}$ fresh weight) and the fruit sac $(2.243 \mathrm{mg} / \mathrm{g}$ fresh weight) respectively. The highest hesperetin content was
} 
detected in the fruit sac $58.43(\mu \mathrm{g} / \mathrm{g}$ dry weight) followed by fruit peel $(32.49 \mu \mathrm{g} / \mathrm{g}$ dry weight) but was not traced in the leaves. A different pattern can be seen in the distribution of quercetin in which the highest content was detected in the fruit peel $(112.47 \mu \mathrm{g} / \mathrm{g}$ berat kering) and the lowest found in the fruit sac $(89.4947 \mu \mathrm{g} / \mathrm{g}$ dry weight). Quercetin also found in the leaves of $C$. aurantifolia $(92.71 \mu \mathrm{g} / \mathrm{g}$ dry weight). Overall, it can be concluded that hesperetin and quercetin compunds are accumulated at different levels in different parts of the C. aurantifolia.

Keywords: Citrus aurantifolia, hesperetin, quercetin, total soluble polyphenol

\section{PENDAHULUAN}

Jeruk nipis atau Citrus aurantifolia merupakan jenis buah yang mudah ditemukan disemua iklim, dimanfaatkan untuk beragam keperluan khususnya bahan pangan secara tradisional telah lama digunakan sebagai kosmetik dan bahan obat untuk mengobati berbagai jenis penyakit (Grabley dan Thiericke, 1999). Berbagai penelitian menunjukan bahwa $C$ aurantifolia memiliki aktifitas-aktifitas anti bakteri (Aibinu et al., 2007) dan antioksidan yang tinggi (Anagnostopoulou et al., 2005). Citrus aurantifolia diketahui memiliki senyawa-senyawa polifenol yang bersifat antioksidan termasuk senyawasenyawa flavonoids spesifik seperti rutin, naringenin, hesperidin, hesperetin, rutin, quercetin, dan limonoids (Gattuso et al., 2007).

Hesperetin dan quercetin adalah aglikon dari glikosida hesperidin dan quercitrin. Quercetin dapat ditemukan pada beragam sayuran dan buah-buahan dan telah lama dimanfaatkan dalam industri nutraseutikal dan farmaseutikal sebagai supplemen kesehatan dan food additives karena aktifitas antioksidannya yang tinggi (Agnes et al., 2008). Hasilhasil penelitian melaporkan bahwa quercetin memiliki aktifitas-aktifitas anti inflamasi, anti hipertensif, vasodilator, anti obesitas, menurunkan kadar kolestrol dalam darah dan anti ateroskerotik (David et al., 2016). Hesperetin diketahui memiliki sifat anti kanker dan anti bakteri (Aranganathan et al, 2008), serta antioksidan dan antiinflamasi (Yang et al., 2012). Hesperetin juga memiliki aktifitas vasolidator sehingga berpotensi menurunkan tekanan darah pada kasuskasus hipertensi. Saat ini senyawa hesperetin dan quercetin murni banyak dimanfaatkan oleh industry-industri farmaseutikal dan nutraseutikal sebagai bahan aditif pada produk-produk suplemen kesehatan.

Senyawa golongan polifenol termasuk quercetin dan hesperetin tersebar pada berbagai bagian tanaman dengan konsentrasi yang berbeda-beda (Gözlekçi et al., 2011). Pola sebaran ini perlu diteliti sehingga proses ekstraksi senyawasenyawa yang diinginkan menjadi lebih efektif dan efisien. Tujuan dari penelitian ini adalah mengetahui konsentrasi polifenol terlarut, hesperetin dan quercetin pada daun, kulit buah, dan isi buah $C$. aurantifolia

\section{METODE PENELITIAN \\ Bahan dan Alat}

Bahan yang digunakan adalah daun, kulit, dan isi buah $C$. aurantifolia, metanol $70 \%$, bufer tris- $\mathrm{HCl} 0.35 \mathrm{M}$, pyrogallol, sodium diethyl-dithiocarbamate (NaDEDTC), $\mathrm{HCl}$, trifluoroacetic acid (TFA), senyawa standar quercetin dan hesperetin. Seluruh bahan kimia dan senyawa standar yang digunakan berkualitas pro analis (Sigma, USA).

Alat yang digunakan adalah mesin pengering freeze drier (Edwards, Britain), millipore 0,45 $\mu \mathrm{m}$ (Scheleiner \& Schuell, 
Jerman), mesin sentrifugal (Heraeus Sepatech, Jerman), mesin sistem High Performance Liquid Chromatography (HPLC, Waters, Milford, USA). Penelitian dilakukan di laboratorium Department of Biochemistry and Microbiology, Faculty of Science and Environmental Studies, Universiti Putra Malaysia. Alat dan bahan disediakan oleh institusi yang sama.

\section{Determinasi Total Polifenol Terlarut}

Total polifenol terlarut pada sampel dideterminasi bedasarkan metode Forest dan Bendal (1969).

\section{Penyiapan Larutan Stok}

Dibuat larutan stok sebagai berikut:

1. $0,1 \mathrm{M}$ potassium titanium oxalate dalam akuades

2. 0,35 $\mathrm{M}$ tris- $\mathrm{HCl} \mathrm{pH}$ 6,7 dalam double deionized water

3. Metanol $70 \%$

4. Metanol $10 \%$

\section{Penyiapan Larutan Uji}

Sebanyak masing-masing satu gram sampel segar (daun, kulit buah, isi buah $C$. aurantifolia) dicampur dengan 10 $\mathrm{mL}$ metanol $70 \%$ dan dihaluskan dengan mortar dan pastel yang sudah didinginkan. Larutan sampel kemudian disentrifugasi pada kecepatan 3500 rpm selama 20 menit. Ekstraksi diulang sebanyak 4 kali, supernatan yang dihasilkan selanjutnya digunakan untuk mendeterminasi kandungan polifenol terlarut pada sampel.

Sebanyak $2 \mathrm{~mL}$ larutan potassium titanium oxalate $0,1 \mathrm{M}, 1 \mathrm{~mL} 0,35 \mathrm{M}$ larutan bufer tris- $\mathrm{HCl} \mathrm{pH} 6,7,1,0 \mathrm{~mL}$ ekstrak sampel, $0,5 \mathrm{~mL}$ metanol $70 \%$ dan $5,5 \mathrm{~mL}$ akuades sehingga didapat total 10 $\mathrm{mL}$ larutan campuran. Larutan campuran ini diukur absorbansinya pada panjang gelombang $445 \mathrm{~nm}$ dengan blanko larutan campuran tanpa ekstrak. Total polifenol terlarut dideterminasi dengan membandingkan terhadap kurva standar. Kurva standar menggunakan larutan pyrogallol pada konsentrasi 0 sampai 800 $\mu \mathrm{g} / \mathrm{mL}$.

\section{Determinasi Senyawa Hesperitin dan Quercetin \\ Ekstraksi dan Hidrolisis Sampel}

Prosedur ekstraksi dan hidrolisis sampel dilakukan berdasarkan metode Crozier et al., 1997. Kulit, daun dan isi buah $C$. aurantifolia masing-masing dikeringkan dengan mesin pengering freeze drier selama 3 hari, kemudian dihaluskan sehingga diperoleh sampel serbuk kering. Sebanyak satu gram serbuk kering dimaserasi dengan metanol $60 \%$ yang mengandung $20 \mathrm{mM}$ Na-DEDTC selama 24 jam. Ekstrak diambil sebanyak $20 \mathrm{~mL}$, ditambah dengan $5 \mathrm{~mL}$ larutan $\mathrm{HCl}$ $6 \mathrm{M}$ selanjutnya direfluks pada suhu $90^{\circ}$ selama 2 jam. Sebanyak $500 \mu \mathrm{L}$ ekstrak terhidrolisis diambil dan dicampur $500 \mu \mathrm{L}$ dengan ektrak tidak terhidrolisis, kemudian diambil sebanyak 250 dan diencerkan dengan $250 \mu \mathrm{L}$ akuades. Larutan diatur pada $\mathrm{pH}$ 2,5 dengan penambahan beberapa tetes TFA selanjutnya disaring dengan millipore 0,45 $\mu \mathrm{m}$.

\section{Penyiapan Larutan Standar}

Masing-masing $1 \mathrm{mg}$ hesperetin dan quercetin dilarutkan dalam $2 \mathrm{~mL}$ metanol $100 \%$. Dari larutan tersebut masingmasing diambil $1 \mathrm{~mL}$. dan ditambahkan dengan $20 \mathrm{~mL}$ metanol $62.5 \%$ yang mengandung $20 \mathrm{mM}$ Na-DEDTC. Pada larutan ini ditambahkan lagi $5 \mathrm{~mL} \mathrm{HCl} 6 \mathrm{M}$ kemudian diencerkan dengan $50 \mathrm{~mL}$ akuades.

\section{Penggunaan HPLC}

Senyawa hesperitin dan quercetin pada sampel diuji menggunakan mesin system HPLC yang terdiri dari Maxima 210 chromatography manager, Water 501 HPLC pump, dan Waters 486 tunable absorbance detector. Pemisahan senyawa dilakukan menggunakan kolom 100 x 8 
mm i.d., $4 \mu \mathrm{m} \mathrm{C18}$ Nova-Pak Radial-pak (Waters, USA). Sebagai fase gerak digunakan larutan acetonitrile 27,5\% dengan penambahan beberapa tetes TFA hingga mencapai $\mathrm{pH}$ 2,5. Larutan disaring dengan millipore $0,45 \mu \mathrm{m}$ dan dihilangkan gelembung udara yang terlarut menggunakan ultra sonicater (sonicor, USA) selama 25 menit. Untuk analisis hesperitin dan quercetin, kolom dielusi (dialiri) dengan fase gerak pada kecepatan $1 \mathrm{~mL} / \mathrm{menit}$. Sebanyak $20 \mu \mathrm{L}$ masingmasing standard dan sampel secara terpisah disuntikan kedalam mesin HPLC. Jejak senyawa standar dan seyawasenyawa yang duiji dalam sampel dimonitor pada absorbansi $370 \mathrm{~nm}$. Kehadiran hesperitin dan quercetin pada sampel diketahui dan dihitung dengan membandingkan terhadap waktu retensi dan tinggi puncak yang diperoleh pada standar (Gambar 1, 2, dan 3).

\section{HASIL DAN PEMBAHASAN Kadar Total Polifenol Terlarut}

Uji linearitas menggunakan senyawa standar pyrogallol pada panjang gelombang $485 \mathrm{~nm}$ menghasilkan kurva standar dengan persamaan $\mathrm{Y}=0.0007 \mathrm{X}$ dengan nilai $\mathrm{R}^{2}=0,998$ (Gambar 1). Dari persamaan ini diperoleh kadar total polifenol terlarut pada sampel seperti terlihat pada Tabel 1 .

Kandungan total polifenol paling tinggi yaitu $69,54 \mathrm{mg} / \mathrm{g}$ berat basah terdapat pada bagian kulit jeruk $C$. aurantifolia sedangkan paling rendah terdapat pada bagian isi buahnya. Rendahnya kandungan total polifenol terlarut pada isi buah dapat disebabkan tingginya kadar air pada bagian isi buah karena kandungan total polifenol dihitung dari berat sampel segar. Namun secara keseluruhan kadar polifenol terlarut pada tanaman $C$. aurantifolia cukup tinggi dibandingkan beberapa jenis buah lainnya (Brat et al., 2006).

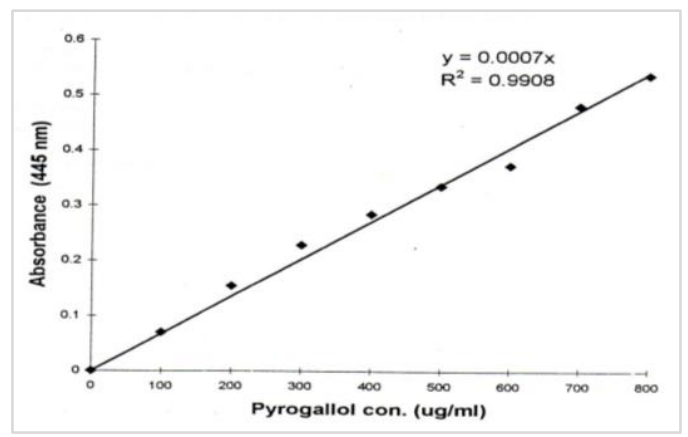

Gambar 1. Kurva Standar Kadar Total Polypenol Terlarut

Tabel 1.Kandungan Total Polifenol Terlarut

\begin{tabular}{ll}
\hline Sampel & $\begin{array}{l}\text { Kadar Polifenol Terlarut } \\
(\mathrm{mg} / \mathrm{g} \text { berat basah) }\end{array}$ \\
\hline Daun & 4,675 \\
Kulit Buah & 6,954 \\
Isi Buah & 2,243 \\
\hline
\end{tabular}

\section{Kandungan Hesperetin dan Quercetin}

Dari kromatogram yang dihasilkan (Gambar 2-5) diketahui bahwa senyawa quercetin paling banyak terdapat pada isi buah, dan senyawa hesperetin paling banyak terdapat pada kulit buah. Kandungan hesperitin dan quercetin pada daun, kulit, dan isi buah $C$. aurantifolia dapat dilihat pada Tabel 2. 
Tabel 2. Kadar Senyawa Hesperetin dan Quercetin pada Daun, Kulit Buah, dan Isi Buah C. aurantifolia

\begin{tabular}{lll}
\hline Sampel & $\begin{array}{l}\text { Hesperitin } \\
(\mu \mathrm{g} / \mathrm{g} \text { berat kering })\end{array}$ & $\begin{array}{l}\text { Quercetin } \\
(\mu \mathrm{g} / \mathrm{g} \text { berat kering })\end{array}$ \\
\hline Daun & - & 92,71 \\
Kulit Buah & 32,49 & 112,47 \\
Isi Buah & 58,43 & 89,49 \\
\hline
\end{tabular}

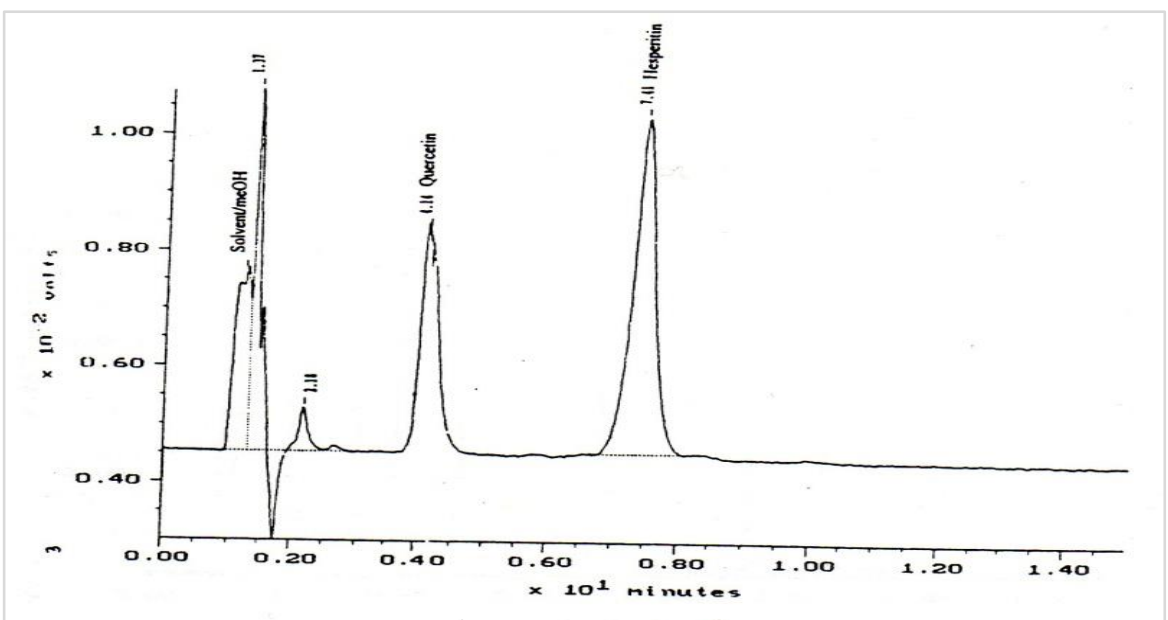

Gambar 2. Kromatogram standar Hesperetin dan Quercetin

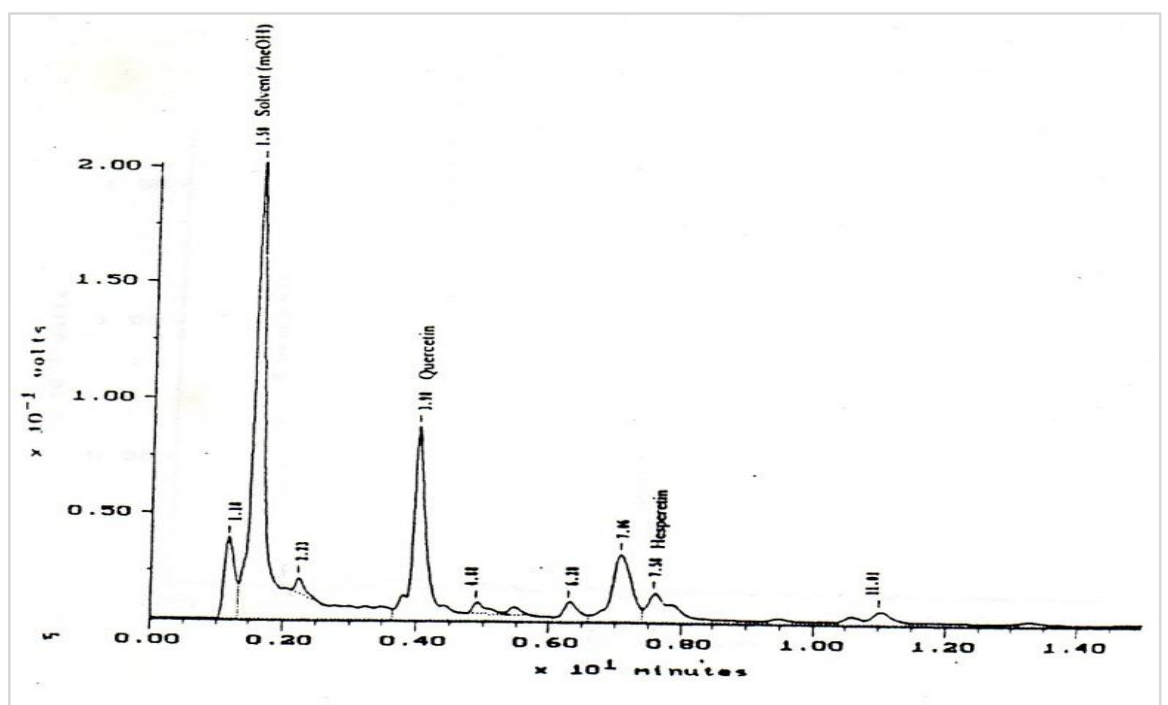

Gambar 3. Kromatogram sampel ekstrak daun C. aurantifolia 


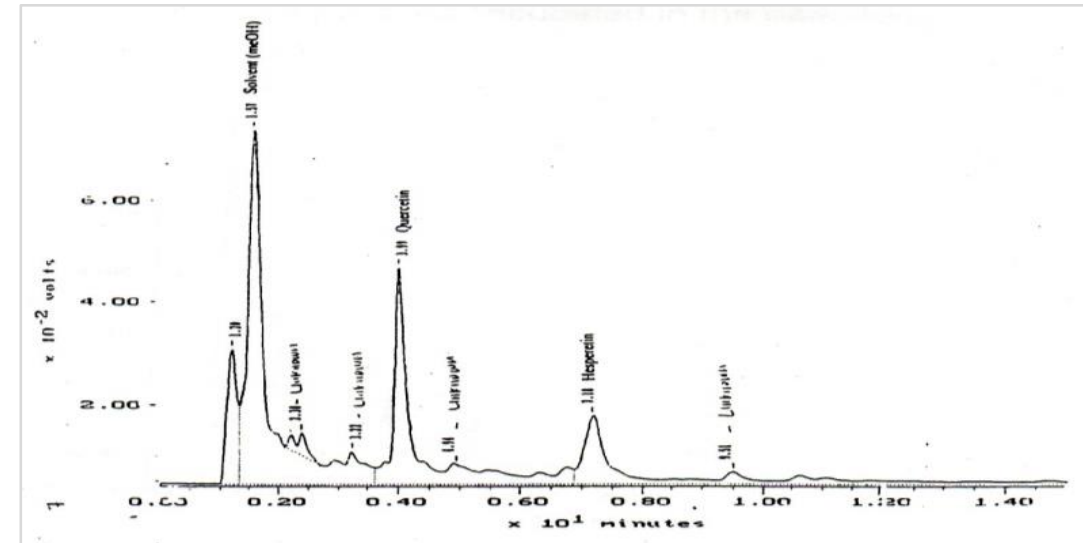

Gambar 4. Kromatogram sampel ekstrak kulit buah C. aurantifolia

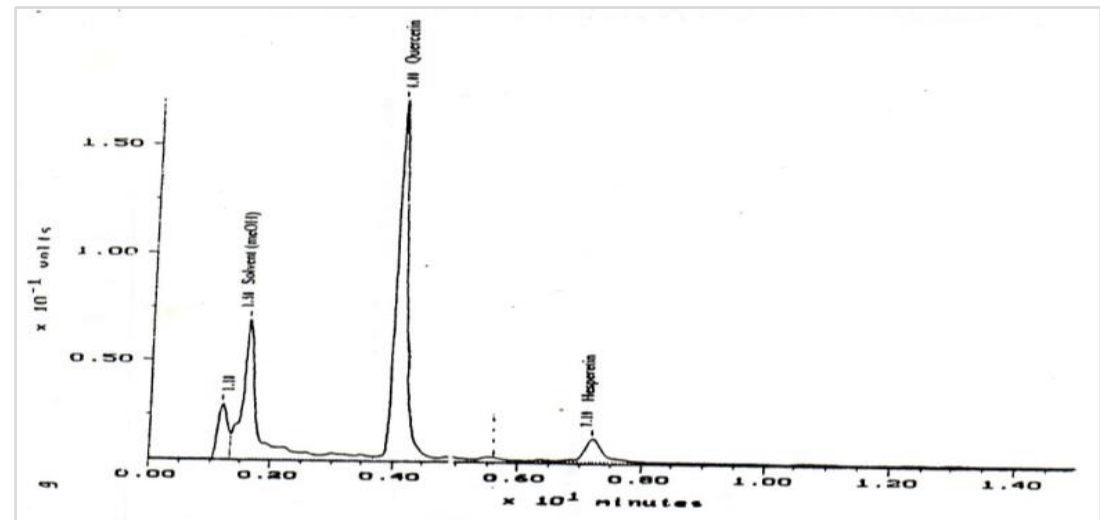

Gambar 5. Kromatogram sampel ekstrak isi buah C. aurantifolia 
Data pada Tabel 2 menunjukan bahwa kandungan quercetin tertinggi $(112,47$ $\mu \mathrm{g} / \mathrm{g}$ berat kering) terdapat pada sampel kulit buah dan kandungan quercetin terendah ada pada isi buah $(89,49 \mu \mathrm{g} / \mathrm{g}$ berat kering). Tingginya kandungan quercetin pada kulit buah sejalan dengan hasil pengukuran kandungan total polifenol terlarut dimana nilai tertinggi didapat dari pengukuran terhadap ekstrak kulit buah. Beberapa penelitian terhadap beberapa species Citrus lainnya juga menunjukan bahwa kadar quercetin paling tinggi terdapat pada bagian kulit buah (Manthey dan Grohmann, 1996) sehingga limbah kulit buah jeruk memiliki nilai ekonomis tinggi sebagai bahan baku yang dapat diolah menjadi produk nutraseutikal yang aman dikonsumsi (Garg et al., 2001).

Pengukuran terhadap kandungan hesperitin menunjukan hasil yang berbeda dimana nilai tertinggi $(58,43 \mu \mathrm{g} / \mathrm{g}$ berat kering) didapatkan dari pengukuran terhadap isi buah $C$ aurantifolia. Beberapa referensi secara umum menunjukan kadar hesperetin yang cukup tinggi terdapat pada jus buah berbagai varietas jeruk. Tingginya kadar hesperitin pada isi buah jeruk ini dapat dikaitkan dengan tingginya aktifitas antioksidan, anti inflamasi dan hepatoprotektif sari buah jeruk (Tomar et al., 2012).

\section{SIMPULAN}

Dari data-data yang dihasilkan pada penelitian ini, dapat disimpulkan bahwa setiap bagian tanaman $C$. aurantifolia mengandung senyawa-senyawa golongan polifenol, hesperitin dan quercetin dengan kadar yang berbeda-beda. Dengan demikian, ekstraksi senyawa yang diinginkan dapat lebih difokuskan pada satu bagian tanaman saja sehingga proses ekstraksi menjadi lebih optimal. Hasil penelitian ini juga menunjukan bahwa limbah kulit jeruk $C$. aurantifolia berpotensi menjadi sumber bahan baku penghasil senyawa murni quercetin karena dalam kulit jeruk mengandung kadar quercetin yang cukup tinggi.

\section{SARAN}

Perlu dilakukan penelitian lebih lanjut untuk mencari metoda ektraksi yang lebih efisien dalam mengekstrak senyawa murni hesperetin dan quercetin dari tanaman C. aurantifolia.

\section{DAFTAR PUSTAKA}

Aghel, N., Z. Ramezani, dan S. 2008. Beiranvand Hesperidin from Citrus sinensis cultivated in Dezful, Iran. Pak J Biol Sci. 11(20): 2451-2453.

Aibinu, I., T. Adenipekun, T. Adelowotan, T. Ogunsanya dan T, Odugbemi T. 2007. Evaluation of the antimicrobial properties of different parts of Citrus aurantifolia (lime fruit) as used locally. African Journal of Traditional Complement and Alternative Medicine. 4(2): 185-90.

Anagnostopoulou, M.A., P. Kefalas, E. Kokkalou, A,N. Assimopoulou dan V.P. Papageorgiou. 2005. Analysis of antioxidant compounds in sweet orange peel by HPLC-diode array detectionelectrospray ionization mass spectrometry. Biomed Chromatogr. 19:138-148.

Aranganathan S., dan N. Nalini. 2013. Antiproliferative efficacy of hesperetin (Citrus flavonoid) in 1,2dimethylhydrazine-induced colon cancer. Phytother Res. 27: 999-1005.

Aranganathan, S., J.P. Selvam dan N. Nalini. 2008. Effect of hesperetin, a citrus flavonoid, on bacterial enzymes and carcinogen-induced aberrant crypt foci in colon cancer rats: a dose-dependent study. J Pharm Pharmacol. 60(10): 1385-1392. 
Boots, W.A. dan R.M. Guido. 2008. Health effects of quercetin: From antioxidant to nutraceutical. European Journal of Pharmacology. 585 (2-3): 325-337.

Brat, P., S. George, A. Bellamy, L. Du Chaffaut. A. Scalbert, L. Mennen, N. Arnault dan M. J. Amiot. 2016. Daily Polyphenol Intake in France from Fruit and Vegetables. The Journal of Nutrition. 6: 2368-2374.

Crozier, A., E. Jensen, M.E.C. Lean dan M.S. McDonald. 1997. Qualitative analysis of flavonoids by reverse-phase high performance liquid chromatogrphy. Journal of Chromatography. 761: 315321.

Forest, G.I., dan D.S. Bendall. 1969. The distribution of polyphenol in the tea plant (Camelia sinensis L.). Biochemistry Journal. 113(5): 741755.

Garg A., S. Garg, L.J.D. Zaneveld dan A.K. Singla. 2001. Chemistry and Pharmacology of the citrus bioflavonoid hesperidin. Phytotherapy Research. 15: 655-669.

Gattuso, G., D. Barreca, C. Gargiulli, U. Leuzzi dan C. Carist. 2007. Flavonoid Composition of Citrus Juices. Molecules. 12(8): 1641-1673.

Gözlekçi, S., O. Saraçoğlu, E. Onursal dan M. Özgen. 2011. Total phenolic distribution of juice, peel, and seed extracts of four pomegranate cultivars. Pharmacogn Mag. 7(26): 161-164.

Grabley, S. dan R. Thiericke. 1999. Drug Discovery from Nature. Springer. London. Springer. Hal. 5-7.

Kawaii, S., Y. Tomono, E. Katase, K. Ogawa K, dan Yano M. 1999. Quantitation of flavonoid constituents in Citrus fruits. J Agric Food Chem. 47: 35653571 .

Manthey, J.A. dan K. Grohmann. 1996. Concentrations of hesperidin and other orange peel flavonoids in citrus processing byproducts citrus and subtropical products laboratory. $J$. Agric. Food Chem. 44 (3): 811-814.

Takumi, H., H. Nakamura, T. Simizu, R. Harada, T. Kometani T. Nadamoto dan R. Mukai. 2012. Bioavilability of orally administered water-dispersible hesperetin and its effect on peripheral vasodilatation in human subjects: Implication of endothelial functions of plasma conjugated metabolites. J. Food Funct. 3(4): 389-398.

Tomar, A., M. Mall M dan P. Rai. 2013. Pharmacological Importance of Citrus Fruits. Int J Pharm Sci Res. 4(1): 156160.

Victor, A., A. David, R. Arulmoli R. dan S. Parasuraman. 2016. Overviews of biological importance of quercetin: A bioactive flavonoid. Pharmacogn Rev. 10(20): 84-89.

Wu, T., Y. Guan dan J. Ye. 2007. Determination of flavonoids and ascorbic acid in grapefruit peel and juice by capillary electrophoresis with electrochemical detection. Food Chem. 100: 1573-1579.

Yang, H.L., S.C. Chen, K. J. S. Kumar, K.N. Yu, S.Y. Tsai, Y.C. Hou dan Y.C. Hseu. 2012. Antioxidant and antiinflammatory potential of hesperetin metabolites obtained from hesperetinadministered rat serum: An ex vivo approach. J. Agric. Food Chem. 60 (1): 522-532. 